\title{
MAJOR REVISIONS OF THE 2005 AISC SEISMIC CODE
}

\author{
I.H. Chen ${ }^{1}$ and W.F. Chen ${ }^{2}$ \\ ${ }^{1}$ Senior Project Engineer, DESIMONE Consulting Engineer, San Francisco, CA, USA \\ ${ }^{2}$ Dean, College of Engineering, University of Hawaii, Honolulu, HI, USA
}

\begin{abstract}
In this paper, the major changes of the 2005 Seismic Provisions for Structural Steel Buildings Part I will be summarized and discussed. The major topics include: Introduction of "Demand Critical Welds" and "Protected Zones"; Expansion of Scope; Integration of ASD into LRFD provisions; Introduction of New Systems and Appendices; General Revisions that applied to all Seismic Load Resisting Systems; and Specific Revisions for the Existing Systems.
\end{abstract}

\section{INTRODUCTION}

The AISC Seismic Provisions for Structural Steel Buildings, hereafter referred to as Seismic Provisions [1,2], which included as part of the AISC Load and Resistance Factor Design (LRFD) Specification for Structural Steel Buildings, hereafter referred to as Specification [3,4], are intended to cover the common design criteria in routine office practice under seismic demands. As new research becomes available, professional practice experiences accumulate and products gain popularity (New Structural Systems), the newly updated version of Seismic Provisions would become available. The languages of the 2005 Seismic Provisions are revised to be consistent with (the CPRP document) ANSI/AISC 358. The major changes of the 2005 Seismic Provisions for Structural Steel Buildings Part I-Structural Steel Buildings can be grouped into the following aspects: (1) Introduction of New Terms; (2) Scope Expansion; (3) Integration of ASD [5] into LRFD provisions; (4) Introduction of New Systems and Appendices; (5) General Revisions that applied to all Seismic Load Resisting Systems; and (6) Specific Revisions for each Existing Systems.

The new 2005 Seismic Provisions introduce new terms such as "Demand Critical Welds" and "Protected Zones" to identify critical areas and their associated requirements in seismic design. Also, the scope of the Seismic Provisions is expanded from "the design and construction" to "the design, fabrication, and erection" of structural members and connections in the seismic load resisting systems (SLRS). The allowable stress design (ASD) alternative (previous part III of 2002 Seismic Provision) has been incorporated into Part I along with Load and Resistance Factor Design (LRFD). In addition, two new systems and 3 new appendices are introduced. They include Buckling-Restrained Braced Frames (BRBF), Special Plate Shear Walls (SPSW), Seismic Design Coefficients and Approximate Period Parameters, Qualifying Cyclic Tests of Buckling-Restrained Braces, and Welding Provisions [6]. Furthermore, changes that applied to all SLRS and each existing systems are provided. These aspects will be discussed in the following sections. The provisions cited from the 2005 code in "exact code language” will be underlined.

\section{INTRODUCTION OF NEW TERMS}

In order to clarify the intention of certain seismic requirements, new terms are introduced in the new 2005 Seismic Provision. Among them, "Demand Critical Welds" and "Protected Zone” are most significant. 


\subsection{Demand Critical Welds}

The newly introduced section replaced the "Additional Requirements in Special Moment Frames (SMF) and Intermediate Moment Frames (IMF)” for Welded Joints of previous Seismic Provisions. Since these welds are required to sustain significant demand from moment connection of SMF and IMF under inelastic deformation, the provisions emphasize the toughness properties of welds. Basically the same requirements applied, except for structures with service temperatures lower than $50{ }^{\circ} \mathrm{F}\left(10^{\circ} \mathrm{C}\right)$, the qualification temperature is clarified as $20^{\circ} \mathrm{F}\left(11^{\circ} \mathrm{C}\right)$ above the lowest anticipated service temperature, or at a lower temperature. The Lowest Anticipated Service Temperature (LAST) is the lowest 1-hour average temperature with a 100 -year mean recurrence interval.

Further, SMAW electrodes classified by AWS A5.1 as E7018 and E8018, and GMAW solid electrodes are exempted from production lot testing when the CVN toughness of the electrode equals or exceeds $20 \mathrm{ft}$-lbs $(27 \mathrm{~J})$ at a temperature not exceeding $-20^{\circ} \mathrm{F}\left(-29^{\circ} \mathrm{C}\right)$ as determined by AWS classification test methods. The manufacture's certificate of compliance shall be considered sufficient evidence of meeting this requirement.

\subsection{Protected Zone}

Protected zone is defined as Area of members in which limitations apply to fabrication and attachments. In other words, it is the zone expected to undergo inelastic deformation, such as plastic hinging zone and beam-column Panel Zone. The newly introduced section combines the old sections "Other Connections" and "Discontinuities” for Welded Joints. In general, provisions are made to avoid discontinuities cause be welding, rapid change of section, penetrations, or construction caused flaws.

\section{SCOPE EXPANSION}

The applicability of the Seismic Provisions has been modified to depend on the response modification coefficient, $\mathrm{R}>3$, (as specified in the applicable building code) regardless of seismic design category. In the absence of local building code, the ASCE [7,8] should govern. Additionally, the scope of the Seismic Provisions is expanded from "the design and construction" to "the design, fabrication, and erection" of structural members and connections in the seismic load resisting systems (SLRS). As a result a new section "Contract Documents, Shop Drawings and Erection Drawings" is added.

\subsection{Contract Documents, Shop Drawings and Erection Drawings}

In general all contract documents (structural design drawings and specifications), shop and erection drawings shall include items required by the Specification and the following, as applicable:

(1) Designation of the members and connections that are part of the seismic load resisting system.

(2) Connection material specifications and sizes. (Shop drawings do not required sizes; Erection drawings required field conditions.) 
(3) Locations of demand critical welds.

(4) Locations and dimensions of protected zones

(5) Welding requirements as specified in Appendix W. (Erection drawings required field conditions.)

Additional requirements for each of the three documents are listed in Section 3.1.1 to 3.1.3.

\subsubsection{Structural Design Drawings and Specifications:}

(1) Designation of the seismic load resisting system (SLRS)

(2) Configuration of the connections

(3) Lowest anticipated service temperature (LAST) of the steel structure, if the structure is not enclosed and maintained at a temperature of $50^{\circ} \mathrm{F}\left(10^{\circ} \mathrm{C}\right)$ or higher.

(4) Locations where gusset plates are to be detailed to accommodate inelastic rotation.

For connections and applications not specifically addressed by the Provisions (Code of Standard Practice listed in Specification), the appropriate requirements should be included, such as nondestructive testing requirements beyond Appendix Q, bolt hole fabrication requirements, bolting requirements, and welding requirements.

\subsubsection{Shop Drawings:}

(1) Gusset plates drawn to scale when they are detailed to accommodate inelastic rotation.

For connections and applications not specifically addressed by the Provisions, the appropriate requirements should be included, such as bolt hole fabrication requirements, bolting requirements, and welding requirements.

\subsubsection{Erection Drawings:}

(1) Locations of pretensioned bolts.

For connections and applications not specifically addressed by the Provisions, the appropriate requirements should be included, such as bolting requirements, and welding requirements.

\section{ALLOWABLE STRESS DESIGN (ASD) INTEGRATION}

In the past, the allowable stress design (ASD) alternative [2,5] has always been documented separately as Part III of Seismic Provisions, while the Part I is for LRFD. However, in the 2005 version, the ASD has been incorporated into Part I along with Load and Resistance Factor Design (LRFD). Generally the conversion factors from strength level to allowable stress level is 1.5 or 0.67 $(=1 / 1.5)$, except certain controlling limit states "1.67" is specified. Please see Table 4.1 for tabulated conversions between LRFD and ASD when 1.67 Factor is applied. 
Table 4.1. LRFD and ASD Conversion Factors

\begin{tabular}{c|c|c|c}
\hline Code Section & Description & LRFD & ASD \\
\hline 8.3 & Columns Strength & $\mathrm{P}_{\mathrm{u}} / \phi_{\mathrm{c}} \mathrm{P}_{\mathrm{n}}>0.4, \phi_{\mathrm{c}}=0.9$ & $\Omega_{\mathrm{c}} \mathrm{P}_{\mathrm{a}} \mathrm{P}_{\mathrm{n}}>0.4, \Omega_{\mathrm{c}}=1.67$ \\
\hline 12.3 & $\begin{array}{c}\text { Required Axial Strength in } \\
\text { Chord of STMF }\end{array}$ & $0.45 \phi \mathrm{P}_{\mathrm{n}}, \phi=0.9$ & $0.45 \mathrm{P}_{\mathrm{n}} / \Omega, \Omega=1.67$ \\
\hline $15.2 \mathrm{~b}$ & $\begin{array}{c}\text { Link Shear Strength of EBF } \\
16.2 \mathrm{a}\end{array}$ & $\begin{array}{c}\phi_{\mathrm{v}} \mathrm{V}_{\mathrm{n}}, \phi_{\mathrm{v}} \mathrm{V}_{\mathrm{pa}}, 2 \phi_{\mathrm{v}} \mathrm{M}_{\mathrm{pa}} / \mathrm{e}, \\
\phi_{\mathrm{v}}=0.9\end{array}$ & $\mathrm{~V}_{\mathrm{n}} / \Omega_{\mathrm{v}}, \mathrm{V}_{\mathrm{pa}} / \Omega_{\mathrm{v}}, 2\left(\mathrm{M}_{\mathrm{pa}} / \mathrm{e}\right) / \Omega_{\mathrm{v}}$, \\
$\Omega_{\mathrm{v}}=1.67$
\end{tabular}

Please note that when 1.67 is specified for ASD conversion, the reduction factor $\phi=0.9$ always accompanied. In other words, 1.5 conversion factor still prevails, because 1.67 =1.5/0.9.

\section{INTRODUCTION OF NEW SYSTEMS AND APPENDICES}

Two new structural systems and 3 new appendices are introduced into the 2005 Seismic Provisions. The two new structural systems are "Buckling-Restrained Braced Frames (BRBF)" and "Special Plate Shear Walls (SPSW)". The three new appendices are "Seismic Design Coefficients and Approximate Period Parameters”, "Qualifying Cyclic Tests of Buckling-Restrained Braces”, and "Welding Provisions". Among them, the "Welding Provisions" is non-mandatory and will later be replaced by AWS D1.8. These new sections will be discussed in the following sections.

\subsection{Buckling-Restrained Braced Frames (BRBF)}

Buckling-restrained braced frames are a special class of concentrically braced frames, where the bracing members can yield in compression without buckling, see Figure 1. Therefore, these braces can dissipate energy through stable tension-compression yield cycles.

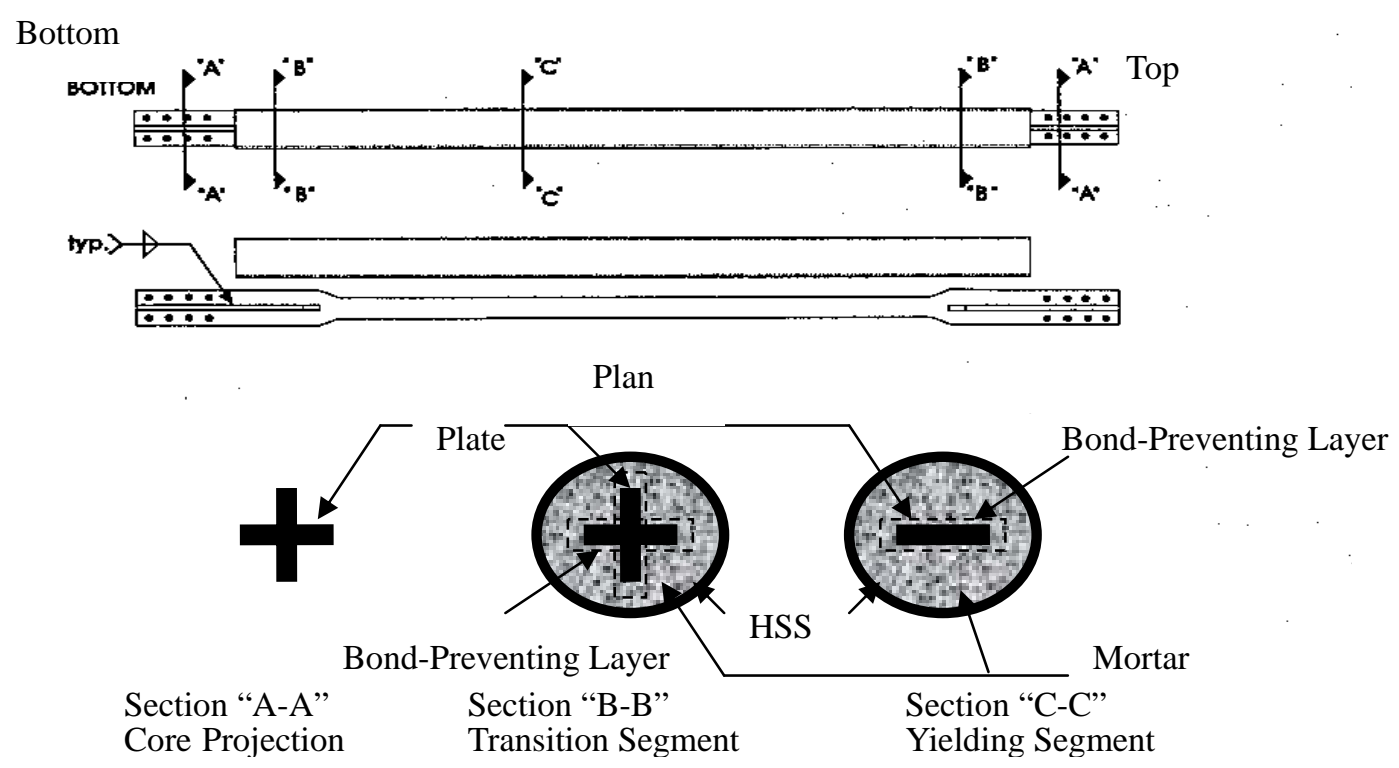

Figure 1. Details of a Buckling Restrained Brace 
Bracing members shall be composed of a structural steel core and a system that restrains the steel core from buckling. The brace design axial strength should solely rely on the steel core, $\phi \mathrm{P}_{\mathrm{ysc}}=\mathrm{F}_{\mathrm{y}} \mathrm{A}_{\mathrm{sc}}$, where $\mathrm{A}_{\mathrm{sc}}$ is the net area of steel core. When steel core's plates are 2" (50mm) or thicker, notch toughness requirements for heavy sections in the code should apply. Buckling-restraining system shall ensure no buckling of steel core, including both local and overall buckling, for deformations corresponding to 2.0 times the design story drift. Bracing connections shall have minimum strength of 1.1 times the adjusted brace strength in compression. The qualifying cyclic tests should conform to Appendix T.

For bracing configurations, V-type and inverted-V-type shall be allowed only if 1) the supporting beams are continuous between columns and laterally brace at both flanges; 2)all gravity loadings including dead and live load can be supported without the braces. K-type braced frames are not permitted.

For beams and columns, they are to be designed for standard load combinations and meet typical width-thickness limitations. Splices shall have shear strength and $50 \%$ flexural strength of the smaller connected member determined from the limit state of yielding.

\subsection{Special Plate Shear Walls (SPSW)}

Special Plate Shear Walls are constructed of slender unstiffened steel plates (Webs) connected to surrounding horizontal and vertical boundary elements, see Figure 2. (i.e. HBEs and VBEs). All HBEs are rigidly connected to VBEs with moment connections able to develop the expected plastic moment of the HBEs. SPSW are designed to withstand significant inelastic deformations in the webs under design earthquakes. While the HBEs and VBEs adjacent to the webs are designed to remain essentially elastic under the maximum forces that can be generated by the fully yielded webs, except that plastic hinging at the ends of the HBEs is permitted. In order to achieve the intended behavior, the criteria for Webs, Boundary Elements, and Connections are provided.

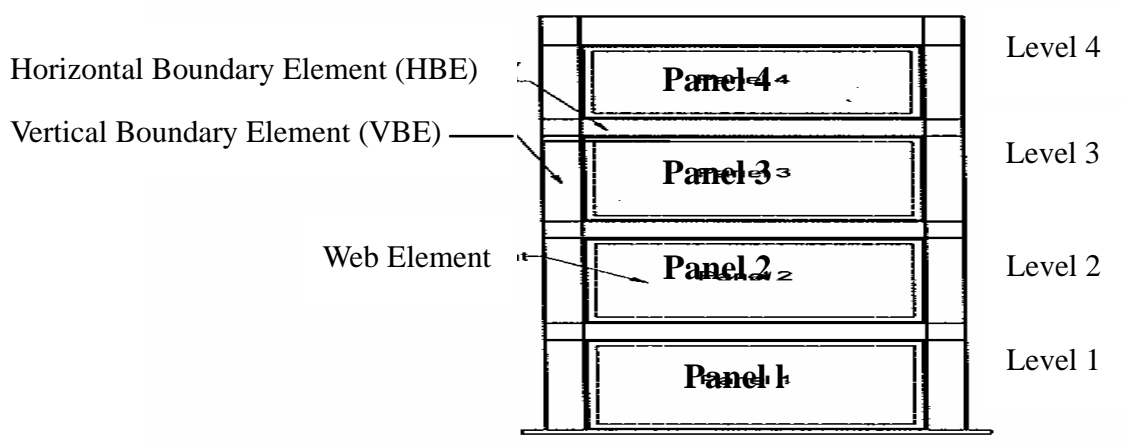

Figure 2. Schematic of Special Plate Shear Walls

\subsubsection{Webs}

The aspect ratio of web panel Length to Height, L/h, shall be limited to 0.8 to 2.5. Any openings in webs shall be bounded on all sides by HBE's and VBE's extending the full width and height of the panel respectively. The panel shear strength $\phi \mathrm{V}_{\mathrm{n}}$ (LRFD) and $\mathrm{V}_{\mathrm{n}} / \Omega$ (ASD) shall be determined as 
$\underline{\mathrm{V}}_{\mathrm{n}}=0.42 \mathrm{~F}_{\mathrm{y}} \underline{\mathrm{t}}_{\mathrm{w}} \underline{\mathrm{L}}_{\mathrm{c}} \underline{\sin 2 \alpha, \phi=0.9, \Omega=1.67}$

where

$\underline{\mathrm{t}}_{\mathrm{w}}$

$\underline{\mathrm{L}}_{\mathrm{cf}}$ _ = clear distance between VBE flanges, in.

$\alpha$ is the angle of web yielding in radians, as measured relative to the vertical, and it is given by:

$$
\tan ^{4} \alpha=\frac{1+\frac{t_{w} L}{2 A_{c}}}{1+t_{w} h\left(\frac{1}{A_{b}}+\frac{h^{3}}{360 I_{c} L}\right)}
$$

$\underline{\mathrm{h}} \quad=$ distance between HBE centerlines, in. (mm)

$\underline{A}_{b}$

$\underline{A}_{c}$

$\underline{\mathrm{I}}_{\mathrm{c}} \_$_ = moment of inertia of a VBE taken perpendicular to the direction of the web plate line, in. ${ }^{4}\left(\mathrm{~mm}^{4}\right)$

$\underline{\mathrm{L}} \quad=$ distance between VBE centerlines, in. (mm)

\subsubsection{Horizontal and Vertical Boundary Elements}

The combination of HBEs and VBEs can be used as the moment frame for a dual system. Therefore, the beam-column moment ratio requirement of Special Moment Frames (SMF) shall be met for all HBE/VBE intersections without considering the effects of webs. Same panel zone and width-thickness requirements as SMF shall be met.

HBE's shall be laterally braced at all intersections with VBE's and at a spacing not to exceed $\underline{0.086 \mathrm{r}_{\mathrm{y}}} \underline{\underline{E}}_{\underline{\mathrm{S}}} \underline{\mathrm{F}}_{\mathrm{Y}}$ (same as SMF). The minimum required brace strength shall be $2 \%$ of flange nominal strength.

The required VBE's strength shall meet seismic column requirements, except the expected yield strength, in tension, of the web calculated at an angle $\alpha$ should also be considered. The stiffness of VBE shall have moment of inertia about an axis perpendicular to the direction of the web plate, $\mathrm{I}_{\underline{C}_{2}}$ not be less than $0.00307 \mathrm{t} \underline{\mathrm{w}} \underline{\mathrm{h}^{4} / \mathrm{L}}$.

\subsubsection{Connections}

Connections of Webs to Boundary Elements shall have required strength of the expected yield strength, in tension, of the web calculated at angle $\alpha$.

Connections of HBE-to-VBE shall satisfy the requirement of Ordinary Moment Frame (OMF), except the required shear strength $\mathrm{V}_{\mathrm{u}}$. The required shear strength $\mathrm{V}_{\mathrm{u}}$ shall not be less than the shear corresponding to moments at each end equal to $1.1 \mathrm{R}_{\mathrm{y}} \underline{\mathrm{M}}_{\mathrm{p}}$ (LRFD) of (1.1/1.5) $\mathrm{R}_{\mathrm{y}} \underline{\mathrm{M}}_{\mathrm{p}}$ (ASD), as appropriate, together with the shear resulting form the expected yield strength in tension of the webs yielding at an angle $\alpha$. 


\subsection{Seismic Design Coefficients and Approximate Period Parameters (Appendix R)}

This appendix contains design coefficients, system limitations and design parameters for seismic load resisting systems included in Seismic Provisions but not yet defined in the applicable building codes. Therefore, the values presented in this appendix shall only be used where neither the applicable building code nor ASCE 7 contain such values. These values are taken from the 2003 NEHRP $[9,10]$.

Table 5.3-1. Design Coefficients and Factors for Basic Seismic-Load-Resisting Systems

\begin{tabular}{|c|c|c|c|c|c|c|c|}
\hline \multirow[t]{3}{*}{$\begin{array}{l}\text { Basic Seismic Load-Resisting } \\
\text { System }\end{array}$} & \multirow{3}{*}{$\begin{array}{l}\text { Response } \\
\text { Modification } \\
\text { Coefficient } \\
\text { R }\end{array}$} & \multirow{3}{*}{$\begin{array}{l}\text { System } \\
\text { Overstrength } \\
\text { Factor } \\
\Omega_{\mathrm{o}}\end{array}$} & \multirow{3}{*}{$\begin{array}{l}\text { Deflection } \\
\text { Amplification } \\
\text { Factor } \\
C_{d}\end{array}$} & \multirow{2}{*}{\multicolumn{4}{|c|}{\begin{tabular}{|l} 
Height \\
Limit (ft) \\
Seismic Design Category \\
\end{tabular}}} \\
\hline & & & & & & & \\
\hline & & & & B \& C & D & $\mathbf{E}$ & $\mathbf{F}$ \\
\hline \multicolumn{8}{|l|}{ Building Frame Systems } \\
\hline $\begin{array}{l}\text { Buckling-Restrained Braced } \\
\text { Frames, non-moment-resisting } \\
\text { beam-column connections }\end{array}$ & 7 & 2 & $51 / 2$ & NL & 160 & 160 & 100 \\
\hline Special Plate Shear Walls & 7 & 2 & 6 & NL & 160 & 160 & 100 \\
\hline $\begin{array}{l}\text { Buckling-Restrained Braced } \\
\text { Frames, moment-resisting } \\
\text { beam-column connections }\end{array}$ & 8 & $21 / 2$ & 5 & NL & 160 & 160 & 100 \\
\hline \multicolumn{8}{|c|}{ Dual Systems with Special Moment Frames Capable of Resisting at Least 25\% of the Prescribed Seismic Forces } \\
\hline $\begin{array}{l}\text { Buckling-Restrained Braced } \\
\text { Frames }\end{array}$ & 8 & $21 / 2$ & 5 & NL & NL & NL & NL \\
\hline Special Plate Shear Walls & 8 & $2 \frac{1}{2}$ & $61 / 2$ & NL & NL & NL & NL \\
\hline
\end{tabular}

Table 5.3-2. Values of Approximate Period Parameters $\mathrm{C}_{\mathrm{t}}$ and $\mathrm{x}$

\begin{tabular}{l|r|r}
\hline Approximate Fundamental Period $T_{a}=C_{t} h_{n}{ }^{x}$, where $h_{n}$ is the height & $\mathbf{C}_{\mathbf{t}}$ & $\mathbf{x}$ \\
\hline Structure Type & 0.03 & 0.75 \\
\hline Buckling-Restrained Braced Frames & 0.02 & 0.75 \\
Special Plate Shear Walls & &
\end{tabular}


The Buckling-Restrained Braces is the heart of the newly introduced Buckling-Restrained Braced Frames. Therefore, this appendix is included to regulate the qualifying cyclic tests for individual buckling-restrained braces and buckling-restrained brace subassemblages. It addresses test specimens for subassemblage and brace, material testing requirements, instrumentation, loading history criteria, test reporting requirements and acceptance criteria.

\subsection{Welding Provisions (Appendix W)}

This is a non-mandatory Appendix that will later be replaced by AWS D1.8. It provides additional details regarding welding and welding inspections. It covers the minimum required information for Contract Documents, Shop and Erection Drawings. It also address the qualification of welding personnel, including QC Welding Inspector, QA Welding Inspectors, and Nondestructive Testing Technicians. General procedure guidelines and special welding provisions are also provided, such as nondestructive testing procedures, filler metals requirements, maximum interpass temperatures, and additional welding provisions for demand critical welds, etc.

\section{GENERAL REVISIONS FOR ALL SEISMIC LOAD RESISTING SYSTEMS}

For all seismic applications, there are basic parameters that applied to all structural systems. These serve as minimum requirements for any seismic performance. If improved performances are desired for specific structural systems, more stringent and/or additional requirements are then added. These basic requirements in Seismic Provisions include: materials; connections, joint, and fasteners; and members. Modifications to these requirements will be discussed in the following sections.

\subsection{Materials}

Additional materials are added in the new 2005 Seismic Provisions. There are A913/A913M Grade 60, A1011 SS Grade 55, or A1011 HSLAS Grade 55. Other steels and non-steel materials in buckling-restrained braced frames are permitted to be used when subject to the associated requirements of BRBF.

The new Seismic Provisions further clarifies how to determine the available strength of element (a member or a connection), and the values of $\mathrm{R}_{\mathrm{y}}$ (material yield overstrength) and $\mathrm{R}_{\mathrm{t}}$ (overstrength of material tensile strength) for different type of materials.

The available strength of the elements shall be $\phi R_{n} \underline{\text { for LRFD and } R_{n}} \underline{\Omega}$ for ASD, where $R_{\underline{n}} \underline{\text { is the }}$ nominal connection strength, which shall be equal to or greater than the required strength. The required strength shall be determined form expected yield stress, $\mathrm{R}_{\mathrm{y}} \mathrm{F}_{\mathrm{y}}$, of an adjoining member. The expected tensile stress, $\mathrm{R}_{\underline{t}} \underline{F}_{\underline{u}}$ and the expected yield stress $\mathrm{R}_{\underline{y}} \underline{F}_{\mathrm{y}}$ are permitted to be used in lieu of $F_{\underline{u}}$ and $F_{y}$, respectively, in determining the nominal strength, $R_{\underline{n}}$, of fracture and yield limit states within the same member that expected strength is determined. In the absence of qualifying test results, $R_{y}$ and $R_{t}$ are tabulated in Table 6.1. 
Table 6.1. $\mathrm{R}_{\mathrm{y}}$ and $\mathrm{R}_{\mathrm{t}}$ Values for Different Member Types

\begin{tabular}{l|c|c}
\hline \multicolumn{1}{c|}{ Application } & $\mathbf{R}_{\mathbf{y}}$ & $\mathbf{R}_{\mathbf{t}}$ \\
\hline Hot-rolled structural shapes and bars: & & 1.2 \\
\hline ASTM A36/A36M & 1.3 & 1.1 \\
\hline ASTM A572/572M Grade 42 (290) & & \\
\hline ASTM A572/572M Grade 50 (345) or Grade 55 (380), & 1.1 & 1.1 \\
A913/A913M, A588/A588M, A992/A992M, & 1.2 & 1.2 \\
\hline A1011SS Grade 55(380), A1011 HSLAS Grade 55 (380) & 1.1 & 1.2 \\
\hline ASTM A529 Grade 50 (345) & & 1.3 \\
\hline ASTM A529 Grade 55 (380) & 1.4 & 1.2 \\
\hline Hollow structural sections (HSS): & & 1.2 \\
ASTM A500 (Grade B or C), A501, A618, and A847 & 1.6 & 1.2 \\
\hline Steel pipe & & \\
ASTM A53/A53M & 1.3 & \\
\hline Plates: & 1.1 & \\
ASTM A36/A36M & & \\
ASTM A572/A572M Gr. 50, A588/A588M & & \\
\hline
\end{tabular}

\subsection{Connections, Joints, and Fasteners}

It is emphasized in the "scope" that the connection for a member of SLRS shall be designed such that a ductile limit state controls. Previously similar statements only appear in the bolted joints sections, which might be misleading in such way that same requirements do not apply to welded joints. Majority of the requirements remain the same for both bolted and welded joints, except as follows.

\subsubsection{Bolted Joints}

In order to expand prohibition of sharing of forces between bolts and welds from same faying surfaces to all cases, the provision "Bolts and welds shall not be designed to share the force in a joint" is added. However, bolted webs combined with welded flanges in moment connections and column splices are still permitted based on deformation compatibility. The desirable ductile limit states are yielding or bearing deformation.

For brace diagonals, oversized holes shall be permitted when the connection is designed as a slip-critical joint, and the oversized hole is in one ply only.

\subsubsection{Welded Joints}

For welded joints, same welding requirements are demanded, except that Welding shall also be performed in accordance with Appendix W. The concept of "Demand Critical Welds" and "Protected Zone" are introduced to welded joints and discussed previously. 
In order to avoid welding into the k-region of hot-rolled shapes, a section regarding Continuity Plates and Stiffeners is added to regulate the corner clip when used in the webs of rolled shape. See Figure 3 for dimension requirements.

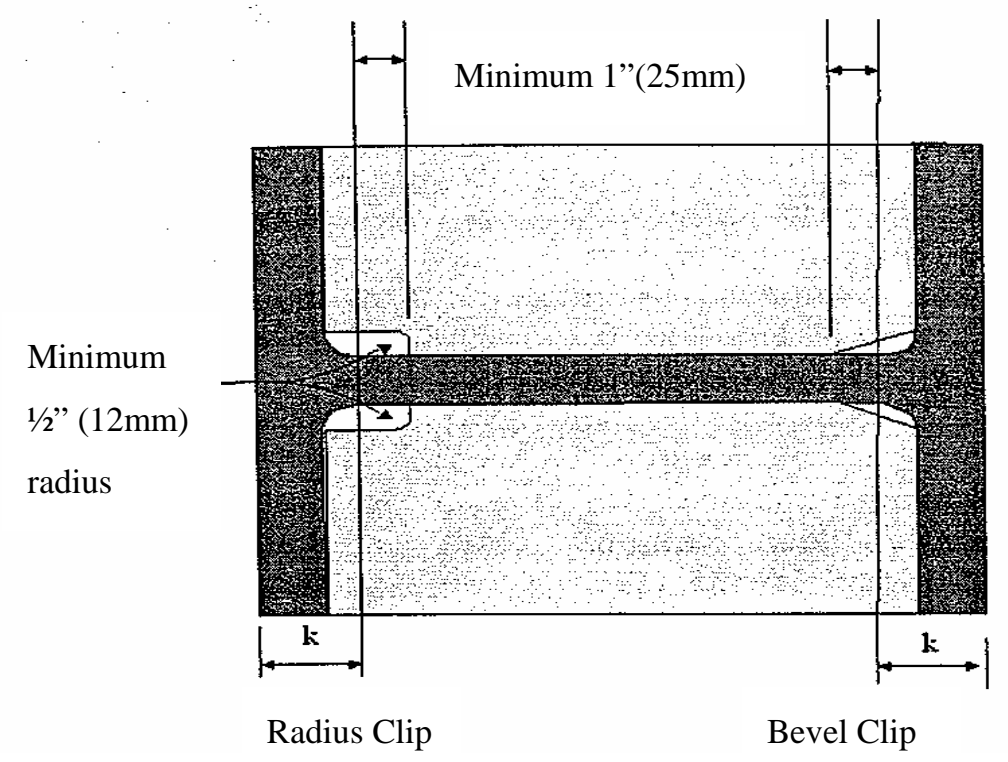

Figure 3. Clip Dimension Requirements

\subsection{Members}

In this section, width-thickness ratio for SLRS and requirement for columns are specified. The contents are essentially the same, except the language modifications and the following clarifications.

For width-thickness ratio, Table B4.1 of the main specification no longer includes values for combined flexure and axial compression, so it is inserted into footnote $\mathrm{j}$ of the new Seismic Provisions.

For Column Splices, to emphasize other special requirements applied, the new Seismic Provisions further list column splice sections number for $\operatorname{SMF}(8.3), \operatorname{IMF}(9.9), \operatorname{OMF}(11.9), \operatorname{SCBF}(13.5)$, and $\operatorname{BRBF}(16.5 b)$.

For Column Bases, unlike the existing specification which only contain general statement, the new specification specifically stated the column base are to be designed for: Required Axial Strength, Shear Strength $\left(2 \mathrm{R}_{\mathrm{y}} \mathrm{F}_{\mathrm{y}} \mathrm{Z}_{\mathrm{x}} / \mathrm{H}\right.$ includes $\mathrm{R}_{\mathrm{y}}$ factor), and Flexural Strength $\left(1.1 \mathrm{R}_{\mathrm{y}} \mathrm{F}_{\mathrm{y}} \mathrm{Z}\right)$.

\section{SPECIFIC REVISIONS FOR EXISTING SYSTEMS}

Existing structural systems include Special Moment Frames (SMF), Intermediate Moment Frames (IMF), Ordinary Moment Frames (OMF), Special Truss Moment Frames (STMF), Special Concentrically Braced Frames (SCBF), Ordinary Concentrically Braced Frames (OCBF), and Eccentrically Brace Frames (EBF). Depending on the performance of the existing structural systems, modifications are made. Among these existing systems, OCBF section is one of the most improved provisions. 
Special moment frames are one of the most ductile and promoted system. They are very well understood and regulated [11-13]. Therefore, not many changes are made, except for further clarifications.

The special requirements of "Demand Critical Welds" and "Protected Zones" are emphasized. For beam-to-column connection, beam flanges, and continuity plates, it is added that connections designed in accordance with ANSI/AISC 358 is satisfactory.

For column-beam moment ratio requirement exceptions, it is clarified that only "moment frame columns" should be accounted in the available shear strength calculations. The language "Restraint" in beam-to-column connection is changed to "Lateral Bracing". It is further clarify that lateral bracing is required only at the top beam flange level of column flanges in beam-to-column connections, when the webs of the beams and column are co-planar.

\subsection{Intermediate Moment Frames (IMF)}

In order to improve the behavior of Intermediate Moment Frames, additional requirements similar to SMF are added [11-13]. These include discontinuities requirements and lateral beam bracing requirements.

To avoid discontinuities, it is added that abrupt changes in beam flange area are not permitted in plastic hinge regions. Drilling of flange holes or trimming of beam flange width is permitted if testing or qualification demonstrates that the resulting configuration can develop stable plastic hinges that meet the requirements in Section $10.2 \mathrm{~b}$ by tests.

For Lateral Bracing of Beams, same provision as SMF is added, except that the unbraced length between lateral braces shall not exceed $0.17 \mathrm{r}_{\mathrm{y}} \underline{\underline{E}}_{s} / \mathrm{F}_{\mathrm{y}_{-}}\left(0.086 \mathrm{r}_{\mathrm{y}} \mathrm{E}_{\mathrm{s}} / \mathrm{F}_{\mathrm{y}}\right.$ for SMF).

\subsection{Ordinary Moment Frames (OMF)}

The Ordinary Moment Frames (OMF) provisions were primarily developed for use with wide flange shapes, however, they may be applied to other shapes such as channels, built-up sections, and hollow structural sections (HSS shapes). Main changes for OMF are regarding connections. It is clarified that the connections in conformance with SMF, or IMF shall be permitted without meeting additional requirement for FR moment connections and Continuity Plates in OMF [11-13]. For FR connection, weld access holes are prohibited in the beam web adjacent to the end-plate in bolted moment end-plate connections. The new provisions further emphasize that Complete-joint-penetration groove welds of beam flanges to column flanges and welds of shear plates and beam webs to columns shall be demand critical welds. For one-sided connections, continuity plate thickness is relaxed to be at least one half of the thickness of beam flange. (Previously, the continuity plate thickness is always greater or equal of beam flange thickness.)

\subsection{Special Truss Moment Frames (STMF)}

Special Truss Moment Frames are expected to withstand significant inelastic deformation within the 
special segments, while other segments remain elastic under design earthquake. Therefore, requirements for the special segment are further clarified and toughened to ensure the desirable behavior.

To avoid confusion, the "design strength" and "axial force" used in previous Seismic Provisions are replaced by "required strength" and "the required axial strength". It is further clarify the contribution of diagonal compressive members in shear strength should be 0.3 times the available compressive strength.

The special segment shall be a protected zone meeting the associated requirements. Diagonal web members within the special segment shall be made of flat bars of identical sections. The required strength of lateral bracing at the end and within the special segment is increased to $6 \% \mathrm{R}_{\mathrm{y}} \mathrm{P}_{\mathrm{nc}}(5 \%$ in previous version), and outside of the special segment is decrease to $2 \% \mathrm{R}_{\mathrm{y}} \mathrm{P}_{\mathrm{nc}}(2.5 \%$ in previous version).

\subsection{Special Concentrically Braced Frames (SCBF)}

Special Concentrically Braced Frames has more ductility over OCBF due to its brace performance. Therefore, the requirements are slightly modified for bracing member, bracing connections, bracing configurations and column splices. In addition, the protected zones for the system are specified.

For Bracing Members, slenderness $\mathrm{KL} / \mathrm{r}$ limit is change to $\leqq 4\left(\mathrm{E} / \mathrm{E}_{\mathrm{y}}\right)^{0.5}$ from $5.87\left(\mathrm{E} / \mathrm{E}_{\mathrm{y}}\right)^{0.5}$; except that $4\left(\mathrm{E} / \mathrm{E}_{\mathrm{y}}\right)^{0.5}<\mathrm{KL} / \mathrm{r}<200$ are permitted, when the available column strength is at least equal to $\mathrm{R}_{\mathrm{y}}$ times nominal strength of connecting brace elements. For required brace strength, the compressive strength requirement is removed; and the tensile strength requirements (when effective net area is less than gross area) are added to be the lesser of the expected tension yield strength $\mathrm{R}_{\mathrm{y}} \mathrm{F}_{\mathrm{y}} \mathrm{A}_{\mathrm{g}}$ and maximum load effect that can be transferred to the brace by the system.

For bracing connections, the required compressive strength based on buckling limit state is increase to $1.1 \mathrm{R}_{\mathrm{y}} \mathrm{P}_{\mathrm{n}}$, while previously only $\mathrm{R}_{\mathrm{y}} \mathrm{P}_{\mathrm{n}}$ is required.

For bracing configuration, it is further clarified that "As a minimum, one set of lateral braces is required at the point of intersection of the V-type (or inverted V-type) bracing, unless the beam has sufficient out-of -plane strength and stiffness to ensure stability between adjacent brace points.”

The protected zone of bracing members in SCBF shall include the center $1 / 4$ and a zone adjacent to each connection equal to the brace depth in the plane of buckling.

The protected zone of SCBF shall include elements that connect braces to beams and columns.

\subsection{Ordinary Concentrically Braced Frames (OCBF)}

To be consistent with other systems, the required member strength from previous code that required the amplified seismic load was dropped and replaced with reduction in $\mathrm{R}$ factor without seismic load amplification. The Slenderness $\mathrm{KL} / \mathrm{r}$ for bracing members in $\mathrm{K}$, $\mathrm{V}$, or inverted-V configurations is further limited to 4 from $4.23\left(\mathrm{E} / \mathrm{F}_{\mathrm{y}}\right)^{0.5}$ in order to prevent undesirable post-buckling behavior resulting from the high difference between compression and tension strength.

Additional requirements are included to eliminate the liberal usage of OCBF. They include Special 
Bracing Configuration Requirements same as SCBF, except that K-type bracing is allowed when meeting the same requirements for V-type and Inverted-V-type Bracing. For bracing connections, "bolt slip" are allowed when designing for a lower force level than is required for other limit states. Bolt slip is not an ultimate limit state and its associated energy dissipation can serve to reduce seismic response [14].

\subsection{Eccentrically Braced Frames (EBF)}

The specifications for Eccentrically Braced Frames are essentially the same as previous, except minor additional clarifications as follows:

(1) Bracing Connections (15.6c): Additional requirements are added such that the diagonal brace connections shall also satisfy the similar required axial tensile and compressive strength of SCBS, including the expected yield strength in tension $\mathrm{R}_{\mathrm{y}} \mathrm{F}_{\mathrm{y}} \mathrm{A}_{\mathrm{g}}$, and $1.1 \mathrm{R}_{\mathrm{y}}$ times the nominal compressive strength $\mathrm{P}_{\mathrm{n}}$.

(2) Beam-to-Column Connections (15.7): If moment connections are required away from the link, the requirement for beam-to-column connections for OMF shall be met.

(3) The Protected Zone (15.9): Links are identified as Protected Zones and shall satisfy the associated requirements.

(4) Demand Critical Welds: (15.10) Locations of Demand Critical Welds are identified as welds attaching the link flanges and the link web to the column, and shall satisfy the associated requirements.

\section{CONCLUSIONS}

In the new 2005 AISC Seismic Provisions, the scope is expanded to cover the "design, fabrication, and erection" of structural members and connections in the seismic load resisting systems (SLRS). The Seismic Provisions become more concise by incorporating the ASD alternatives into LRFD sections. The existing Seismic Provisions are improved and clarified. New terms, such as "Protected Zones" and "Demand Critical Welds", are introduced to clarify the concept of seismic design - that is to ensure ductile limit state at critical elements. Two new structural systems (1) Buckling Restrained Braced Frames and (2) Special Plate Shear Walls are introduced and codified. Accordingly, improved seismic designs should be expected in routine office practice. Hopefully, the expected performance level of steel building under seismic events could be ensured. 


\section{REFERENCES}

[1] AISC, “Seismic Provisions for Structural Steel Buildings”, American Institute of Steel Construction, Chicago, IL, 2005.

[2] AISC, “Specification for Structural Steel Buildings”, ANSI/AISC 360, Chicago, 2005.

[3] AISC, "Prequalified Connections for Special and Intermediate Steel Moment Frames for Seismic Applications”, AISC 353, Chicago, IL, 2005.

[4] AISC, "Seismic Provisions for Structural Steel Buildings”, American Institute of Steel Construction, Chicago, IL, 2002.

[5] AISC, "Load and Resistance Factor Design Specification", American Institute of Steel Construction, 3rd Ed., Chicago, IL, 2001.

[6] AISC, "Specification for Structural Steel Buildings, Allowable Stress Design and Plastic Design”, American Institute of Steel Construction, Chicago, IL, 1989.

[7] ASCE, "Minimum Design Loads for Buildings and Other Structures”, ANSI/ASCE 7-2002, American Society of Civil Engineers, Reston, VA, 2002.

[8] ASCE, “Minimum Design Loads for Buildings and Other Structures”, ANSI/ASCE 7-1998, American Society of Civil Engineers, Reston, VA, 1998.

[9] AWS, “Structural Welding Code Steel”, ANSI/AWS D1.1:2002, American Welding Society, Miami, FL, 2000.

[10] FEMA, "NEHRP (National Earthquake Hazards Reduction Program) Recommended Provisions for Seismic Regulations for New Buildings”, Federal Emergency Management Agency, Washington, DC, 2003.

[11] FEMA, “Recommended Seismic Design Criteria for New Steel Moment-Frame Buildings”, FEMA350, Federal Emergency Management Agency, Washington, DC, 2000.

[12] FEMA, "Recommended Specifications and Quality Assurance Guidelines for Steel Moment-Frame Construction for Seismic Applications”, FEMA353, Federal Emergency Management Agency, Washington, DC, 2000.

[13] FEMA, “NEHRP (National Earthquake Hazards Reduction Program) Recommended Provisions for Seismic Regulations for New Buildings”, Federal Emergency Management Agency, Washington, DC, 2000.

[14] Sabelli, R., "EERI/FEMA NEHRP Professional fellowship report: Research on improving the seismic behavior of earthquake-resistant steel braced frames”, Earthquake Engineering Research Institute, Oakland, CA, 2001. 